\title{
The challenges of integrated farming system development towards sustainable agriculture in Indonesia
}

\author{
Febrina Elia Nababan $^{1 *}$, and Dewi Regina ${ }^{2}$ \\ ${ }^{1}$ Ministry of Village, Development of Disadvantaged Regions and Transmigration \\ ${ }^{2}$ Ministry of Transportation
}

\begin{abstract}
This study was aimed to determine the challenges of developing an Integrated Farming System (IFS). IFS is one of the solutions for agricultural development in Indonesia by integrating agriculture, livestock, fisheries, forestry and other sciences related to agriculture. It is expected to be able to increased land productivity. This research was conducted with a comparative study from various countries such as Brazil, India, US, subSaharan Africa countries regarding development issues, implementation, and constraints that occur in an IFS. The method of study is literature study. The results of the study show that the implementation of the IFS system poses various challenges, including: a) lack of understanding of farmers towards IFS, b) limited ability of farmers to utilize agricultural technology and c) financial support. However, IFS can increase agricultural food security and increased farmer welfare and expand employment. The implementation of IFS requires government support to create opportunities to increase farm scale in line with farmers' income.
\end{abstract}

\section{Introduction}

Covid-19 has had an impact on all sectors, including the agricultural sector. In the face of the Covid-19 pandemic, the government must ensure that the food needs of the community are safely available. In the middle of Pandemic, surprisingly agricultural sector is one of the sectors that grew positively during 2020 and Q1 2021. Indonesia Statistic in 2021 shows 64.56 percent of GDP comes from Industry, Agriculture, Trade, Construction, and Mining. Agriculture including to five biggest sector to support GDP in first quartal 2021. In 2020 the data of the agricultural sector in the fourth quarter of 2020 grew by 2.59 percent year on year (yoy), where the main supporting sub-sector was food crops by 10.47 percent. The growth of the agricultural sector was followed by good export performance as well. BPS data states that the performance of agricultural exports in 2020 increased by 15.78 percent from the previous year, which was Rp. 390.16 trillions to Rp. 451.77 trillions. This shows that the policies taken by the government in the agricultural sector are quite successful so that the agricultural sector is able to survive in the midst of a pandemic. This success certainly needs to be maintained and maintained in order to maintain food security in the long term in the face of uncertainty

* Corresponding author: febrina.elia0302@gmail.com 
over the end of the pandemic. In addition to this, population growth and increasing food needs which are not followed by the availability of agricultural land require an increase in food production per unit area of land in a sustainable manner. One of the sustainable food security strategies is by developing an Integrated Agricultural System (IFS).

In an integrated farming system, every business is interrelated or waste from one production system becomes input for another production system. This can reduce costs and increase production and income [1]. IFS is characterized by the diversity of genetic species, efforts and practices used to achieve the objectives. The synergy between the various types of businesses in agriculture is the basis of the concept of an integrated system. Integrated farming systems have been widely practiced by developing countries, including Indonesia where agricultural land area and access to fertilizers are limited and farmers mostly have narrow lands so that they join the practice of integrated farming systems to meet their needs [2]. IFS implementation has been shown to provide benefits in increasing agricultural competitiveness, increasing productivity and increasing farm incomes by adding value to crop and livestock operations and increasing farmers' adaptability and reducing risks to markets and weather $[3,4,5,6]$. Based on the above discussion, research on the challenges of developing IFS is very important and the results are important inputs for policy makers for Sustainable Agriculture in Indonesia.

\section{Literature review}

Many studies have defined the concept of integrated farming systems differently. IFS has an emphasis on managing interactions between business units so that waste from one component becomes input for other components of the system, reduces the need to purchase and apply expensive and potentially polluting inputs, such as fuel, fertilizers and pesticides, reduces pollution to the environment and increase production or overall income. The interdependence among farms within the system, synergistic transfer of resources and flexibility within the system are important factors for long-term sustainability [6, 7] . Archer et al [2] stated that IFS includes several interacting plant components. These systems include crop rotation, the use of annual cover crops, green manure crops, or intercropping to reduce the need for purchased inputs by improving or retaining nutrients and reducing weeds, disease, and pest stress on farms. Radhamani et al. [8] defined IFS as a holistic farming approach that aims to minimize risks, increase production and profits while increasing the utilization of organic waste and crop residues. Jayanthi, C. \& Vennila [9] stated that IFS is a system that combines two or more farming businesses, with the concept of used materials becoming something more useful so that input output ties are established between commodities.

IFS can be applied to offset the growing demand for agriculture, especially food crops without damaging the environment and employment. The implementation of IFS is the right choice to increase farmers' income and at the same time optimally utilize agricultural resources. IFS is defined as a biologically integrated farming system that integrates natural resources and regulatory mechanisms into agricultural activities to achieve increased productivity, so as to maintain sustainable production, maintain agricultural income, reduce current sources of environmental pollution generated by agriculture and sustain various functions agriculture [10].

IFS implementation has economic benefits for farmers through economic scope. It is cheaper to produce two or more products simultaneously than to produce them separately. The integrated system reduces production costs due to complementarity in production such as the use of screening grain or crop residues for animal feed and subsequent application of manure to the soil as fertilizer. The benefits of economic scope tend to be more pronounced for small farms than for large farms, so there is a stronger incentive for integration in small farms [2]. On the other hand, integrated systems increase the complexity of management due 
to the need to understand and coordinate different types of agricultural enterprises. If this complexity cannot be handled properly it can reduce productivity and create incentives for integration [11].

Based on some of the concepts above, it can be concluded that IFS is a system that integrates various agricultural business units, which is based on: input-output linkages between commodities through the use of waste so that they can increase productivity and can increase farmers' income.

\section{Methods}

On the challenge of developing an integrated farming system is carried out using the literature study method. This method is done by describing the findings through narration. The focus of the research looks at the challenges of developing IFS from best practices in various countries such as Brazil, India, US, sub-Saharan Africa countries. This research approach helps in formulating what are the challenges and how to overcome these challenges so that IFS can be implemented in various parts of Indonesia to maintain food security and agricultural sustainability in Indonesia.

\section{Results and discussion}

\subsection{IFS Implementation in various countries}

IFS implementation has been carried out in various countries. Garret et al. [3] stated that IFS provides an opportunity to integrate conservation and agricultural growth in the Brazilian Amazon and Cerrado to meet sustainable development challenges. IFS is also a mutually beneficial economic and environmental solution compared to existing extensive livestock management practices and other pasture intensification alternatives. The economic benefit of this system is better income. IFS is proven to generate almost three times more revenue and seven times more protein.

An economic feasibility study based on seven years of experimental data in Mato Grosso shows that integrated farming has a shorter payback period (4 years) than continuous soybean and corn production (6 years) and continuous grazing (5 years). Integrated agriculture yields US\$ 638/ha and $299 \mathrm{~kg}$ of human digestible protein (HDP)/ha with a stocking rate of 5.8 animal units/ha. The environmental impact per $\mathrm{kg}$ of HDP is: $39 \mathrm{~kg}$ of carbon dioxide equivalent, $0.38 \mathrm{~kg}$ of Nitrogen and $300 \mathrm{~kg}$ of water. However, IFS implementation has challenges in the form of high initial costs, greater managerial, market access, credit, and limited information. Agricultural operator transitions are urgently needed and can be implemented by helping young farmers acquire the new capital and skills needed to enter the agricultural sector.

Brazil's existing agricultural development strategy of providing low-interest loans for machinery investment and operating costs has so far been insufficient to drive intensification. There is a need to motivate ranchers and farmers to intensify their production, namely: 1) financially intensive 2) improvement of pilot farms using successful IFS practices and widespread training seminars, 3) increasing access and simplifying public loan terms, 4) improving supply chain infrastructure and access to machinery for cropping systems, and 5) increasing positive incentives for intensification through value chain enhancement and payments for environmental services.

In India, the implementation of IFS is driven by an important issue, namely the rapid population growth but cannot be accompanied by the expansion of the production area for community food. Conventional agriculture that has been carried out so far has caused various 
problems including economic and ecological problems. Conventional Agriculture leads to increased costs of energy-based inputs, reduced farm income, etc. In addition, conventional agriculture also raises ecological problems such as poor ecological diversity, soil erosion, and soil and water pollution. IFS is one of the best options to improve the welfare of smallholders to ensure sustainable livelihoods (Table 1). IFS is not only able to improve the nutritional and economic status of farming families but also increase employment opportunities and optimally utilize agricultural resources. Resource integration is carried out through a combination of soil, water and animal resources from a farm through careful planning including recycling of biological resources. The development of IFS continues to be carried out to contribute to the national goal of doubling farmers' income and overcoming the problem of malnutrition [12] .

Table 1. Economic viability of integrated farming system research models developed in different Indian States

\begin{tabular}{|c|c|c|c|c|c|}
\hline State & $\begin{array}{l}\text { Prevailing } \\
\text { system }\end{array}$ & $\begin{array}{c}\text { Net } \\
\text { Return }\end{array}$ & Integrated Farming System & $\begin{array}{c}\text { Net } \\
\text { returns }\end{array}$ & References \\
\hline \multirow[t]{2}{*}{ Karnataka } & \multirow[t]{2}{*}{$\begin{array}{l}\text { rice }- \text { rice } \\
\text { system }\end{array}$} & \multirow[t]{2}{*}{21599} & $\begin{array}{l}\text { Rice-fish (pit at the center of } \\
\text { the field) - poultry (reared } \\
\text { separately) }\end{array}$ & 62,977 & \multirow[t]{2}{*}{$\begin{array}{l}\text { Chnnabasavanna et } \\
\text { al., } 2007 \text { [21] }\end{array}$} \\
\hline & & & $\begin{array}{l}\text { Rice-fish (pit at one side of the } \\
\text { field) - poultry(shed on fish pit) }\end{array}$ & 49,303 & \\
\hline \multirow[t]{2}{*}{ Goa } & \multirow[t]{2}{*}{ Cashew } & \multirow[t]{2}{*}{36,330} & Coconut + forage + dairy & 32,335 & \multirow{2}{*}{$\begin{array}{l}\text { Manjunath et al., } \\
2003 \text { [22] }\end{array}$} \\
\hline & & & $\begin{array}{l}\text { Rice-brinjal }(0.5 \text { ha })+\text { Rice- } \\
\text { Cowpea }(0.5 \text { ha })+\text { mushroom } \\
+ \text { poultry }\end{array}$ & 75,360 & \\
\hline \multirow{2}{*}{$\begin{array}{l}\text { Madhya } \\
\text { Pradesh }\end{array}$} & \multirow{2}{*}{$\begin{array}{l}\text { Arable } \\
\text { farming }\end{array}$} & \multirow[t]{2}{*}{24,093} & Mixed farming +2 cow & 37,668 & \multirow{2}{*}{$\begin{array}{l}\text { Tiwari et al., } 1999 \\
\text { [23] }\end{array}$} \\
\hline & & & $\begin{array}{l}\text { Dairy }(2 \text { cows })+15 \text { goats }+10 \\
\text { poultry }+10 \text { duck }+ \text { fish }\end{array}$ & 44,913 & \\
\hline \multirow[t]{9}{*}{ Tamilnadu } & \multirow[t]{2}{*}{$\begin{array}{l}\text { Rice-rice- } \\
\text { blackgram }\end{array}$} & 8,312 & Rice-rice-cotton +maize & 15,009 & $\begin{array}{l}\text { Shanmugasundaram } \\
\text { et al.,1993 [24] }\end{array}$ \\
\hline & & & $\begin{array}{l}\text { Rice-rice-cotton } \\
+ \text { maize+poultry/fish }\end{array}$ & 17,209 & \multirow[t]{2}{*}{$\begin{array}{l}\text { Shanmugasundaram } \\
\text { et al.,1995 [25] }\end{array}$} \\
\hline & Rice-rice & 15,299 & $\begin{array}{l}\text { Rice-rice- } \\
\text { Azolla/Calotropis+Fish }\end{array}$ & 17,488 & \\
\hline & $\begin{array}{l}\text { rice-rice-rice- } \\
\text { fallowpulses }\end{array}$ & 13,790 & $\begin{array}{l}\text { Rice-rice-rice-fallow- } \\
\text { cotton+maize+duck cum fish }\end{array}$ & 24,117 & $\begin{array}{l}\text { Ganesan et al., } 1990 \\
{[26]}\end{array}$ \\
\hline & \multirow{3}{*}{$\begin{array}{l}\text { Cropping } \\
\text { alone }\end{array}$} & \multirow[t]{3}{*}{36,190} & Cropping+fish+poultry & 97,731 & \multirow{3}{*}{$\begin{array}{l}\text { Jayanthi et al., } 2001 \\
{[27]}\end{array}$} \\
\hline & & & Cropping+fish+pigeon & 98,778 & \\
\hline & & & Cropping+fish+goat & 13,1118 & \\
\hline & \multirow[t]{2}{*}{ Rice } & \multirow[t]{2}{*}{22,971} & Rice+fish & 28,569 & \multirow{2}{*}{$\begin{array}{l}\text { Balusamy et al., } \\
2003[28]\end{array}$} \\
\hline & & & Rice+Azolla+fish & 31,788 & \\
\hline $\begin{array}{l}\text { Uttar } \\
\text { Pradesh }\end{array}$ & $\begin{array}{l}\text { Crops } \\
\text { (Sugarcanewh } \\
\text { eat) }\end{array}$ & 41,017 & $\begin{array}{l}\text { Crops } \\
\text { (Sugarcane+wheat)+dairy }\end{array}$ & 47,737 & Singh, 2004 [29] \\
\hline \multirow[t]{3}{*}{ Maharashtra } & \multirow{3}{*}{$\begin{array}{l}\text { Cotton }(\mathrm{K})+ \\
\text { Groundnut } \\
(\mathrm{S})\end{array}$} & \multirow[t]{3}{*}{$(-) 92$} & $\begin{array}{l}\text { Blackgram( K) - Onion (R)- } \\
\text { Maize+cowpea }\end{array}$ & 1,304 & \multirow[t]{3}{*}{$\begin{array}{l}\text { Shelke et al., } 2001 \\
{[30]}\end{array}$} \\
\hline & & & Crop+dairy+sericulture & 3,524 & \\
\hline & & & Crop + dairy & 5,121 & \\
\hline
\end{tabular}

Source : Patra \& Samal (2018)

IFS implementation in America faces the challenge of agricultural specialization. The development of US agriculture is now increasingly specialized and able to maintain food security and affordability. But on the other hand, this raises concerns for animal welfare, environmental degradation, and loss of biodiversity. An alternative to specialized agriculture is the integration of crops and livestock on a farm/IFS scale (Table 2). IFS has been shown to improve soil quality, reduce dependence on external inputs, contribute to pest 
management, enhance the conservation of vital wild biodiversity, strengthen agricultural economies, and provide food security benefits to communities.

Table 2. Increased profits from livestock in integrated agroecosystems

\begin{tabular}{|l|c|c|}
\hline \multicolumn{1}{|c|}{ Agroecosystem } & $\begin{array}{c}\text { Profits from animals } \\
\text { (excludes profits from } \\
\text { crops) }\end{array}$ & References \\
\hline $\begin{array}{l}\text { Cattle grazing winter ryegrass } \\
\text { cover crop }\end{array}$ & $\$ 170-\$ 560 /$ ha & (Bransby, 1999) [31] \\
\hline $\begin{array}{l}\text { Cattle grazing winter ryegrass } \\
\text { cover crop }\end{array}$ & $\$ 227-323 / \mathrm{ha}$ & (Hill et al., 2004) [32] \\
\hline $\begin{array}{l}\text { Sheep and broilers grazing for } \\
\text { five months during spring-fall } \\
\text { growing season }\end{array}$ & $\$ 2,077 / \mathrm{ha}$ & (Lowy, 2009) [33] \\
\hline $\begin{array}{l}\text { Cattle grazing winter ryegrass } \\
\text { or oat cover crop }\end{array}$ & $\$ 200 / \mathrm{ha}$ & (Siri-Prieto et al., 2007) [34] \\
\hline
\end{tabular}

Source : Hilimire, 2013

In implementing IFS, various challenges must be faced, including regulations that have been implemented in the context of specialization. The use of livestock also presents challenges in farming such as nutrition, balance for soil fertility, environmental pollution caused by manure runoff, and soil compaction caused by trampling animals. For successful implementation of IFS in the United States, training programs for novice breeders, breeding initiatives for pasture-resistant animals, and small-scale meat processing facilities must all receive attention and support [13].

In sub-Saharan Africa countries, the development of IFS is capable of producing half of the world's cereals and a third of beef and dairy, making it a livelihood for one billion people. The increasing demand for food needs is driving the intensification of crops and livestock in smallholder farming systems in Africa. The integration of crop and livestock systems contributes to ecologically and economically sustainable growth. In integrated systems, livestock intensification often does not contribute to food crops, but livestock can contribute positively to increasing the productivity of agricultural systems. Similarly, intensification of food crops can provide benefits for livestock and improve natural resource management, especially through increasing the availability of biomass [14].

Various regions in Indonesia have also tried to implement the Integrated Agricultural System (IFS), one of which is the Province of Bali by implementing the Integrated Agricultural System (SIMANTRI). SIMANTRI is a program to encourage the agricultural sector by empowering every agricultural activity as well as the utilization of agricultural and livestock waste which is a component of supporting integration at the Simantri group level. SIMANTRI's activities are oriented towards zero-waste agriculture and produce 4F (food, feed, fertilizer, and fuel). The implementation of this program has had a positive impact in encouraging the growth of agricultural group business activities in Bali, increasing employment opportunities, meeting the needs of food, feed, organic fertilizers and pesticides as well as biogas at the group level as well as for commercial purposes through the support of local government policies (Table 3) [15]. 
Table 3. The results of the study on the implementation of SIMANTRI in province of Bali

\begin{tabular}{|c|c|}
\hline $\begin{array}{l}\text { The results of the study on the implementation of } \\
\text { SIMANTRI in province of Bali. }\end{array}$ & References \\
\hline $\begin{array}{l}\text { Income for farmers per hectare per year from Simantri } \\
\text { activities with crop-livestock integration patterns are } \\
1.07 \text { percent higher than real incomes without crop- } \\
\text { livestock integration. }\end{array}$ & Sukanteri (2013) [35] \\
\hline $\begin{array}{l}\text { Farming carried out with the SIMANTRI system provides } \\
\text { higher profits, savings in fertilizer costs, effectiveness in } \\
\text { the use of inputs or production costs with higher BCR } \\
\text { values, and saves labor costs and increases the price of } \\
\text { organic agricultural products. Receipts with the integrated } \\
\text { system in Bali reached Rp. } 12,561,000 \text { with a profit of Rp. } \\
4,430,000 \text { compared to the partial system (revenue of Rp. } \\
11,717,000 \text { and profit of Rp. } 3,249,000 \text { ). Increased profits } \\
\text { from the integrated system by } 29.19 \text { percent, with a BCR } \\
\text { of } 1.86 \text {. The use of manure/organic has been able to save } \\
\text { the use of inorganic fertilizers by around } 21-63 \text { percent. } \\
\text { The excess of rice production with the integrated system } \\
\text { of rice plants and beef cattle, was able to produce rice } \\
\text { production of } 6,167 \text { kg per hectare with an income of Rp. } \\
4.019 .106\end{array}$ & Pasandaran (2006) [36] \\
\hline $\begin{array}{l}\text { With the coffee-goat integration pattern, the initial income } \\
\text { of farmers was Rp. } 5,721,700 \text { in } 2005 \text {, increasing to Rp. } \\
14,189,200 \text { in } 2008 \text { or an increase of } 148 \text { percent }\end{array}$ & Guntoro et al., 2009 [37] \\
\hline $\begin{array}{l}\text { The integration pattern of corn/horticulture-cow, } \\
\text { supported by irrigation ponds, can increase income from } \\
\text { IDR 4,094,000 in } 2005 \text { to IDR } 9,696,300 \text { in } 2008 \text {, an } \\
\text { increase of } 136.84 \text { percent }\end{array}$ & Adijaya et al., 2009 [38] \\
\hline $\begin{array}{l}\text { Implementation of the SIMANTRI program in locations } \\
\text { is very effective reaching } 98.94 \text {. The average income } \\
\text { before the Simantri program was IDR } 0.606 \text { million per } \\
\text { month and after the Simantri program it was IDR } 1.542 \\
\text { million per month. The results of the analysis of job } \\
\text { opportunities show that the Simantri program also has a } \\
\text { positive and significant impact on the employment } \\
\text { opportunities of farmer households in terms of working } \\
\text { hours before and after the Simantri program, from } 5,222 \\
\text { hours per day to } 9,827 \text { hours per day. }\end{array}$ & Wibawa dan Yasa , 2013 [39] \\
\hline
\end{tabular}

Source : Anugrah et al., 2014

\subsection{Challenges and strategy to implement integrated farming}

Aare et al [16] stated that the implementation of IFS farmers requires various understandings of IFS and skills to be able to apply IFS which has many types of agricultural activities. Farmers must be experts in every type of agricultural production, technical skills such as the use of technology as well as good managerial skills. The need for various knowledge and skills and insights causes farmers to prefer farming that is less diverse in agricultural systems. This need for understanding and skills should be supported by training and mentoring for farmers in implementing IFS.

In addition to knowledge and skills, the large initial costs pose a challenge in implementing the integrated farming model while many farmers have the inability to access 
credit to cover the costs and risks of building an integrated system. Farmers will think not to adopt IFS because they are reluctant to take on larger debts or take risks given the uncertainty about the benefits. In addition, the integrated system requires more manpower, and thus can be a challenge if there is a decrease in the supply of labor in the agricultural sector and an increase in labor costs. Farmers say it is difficult to find or train a skilled workforce to work in an integrated system [3].

Hidayati et al [17] also argue that the obstacle in implementing IFS is firstly understanding the correct IFS concept by farmers. Second, Farmers are also not too sure that IFS will have an impact on increasing agricultural yields and productivity. Third, the development of an integrated agricultural system model that is not in accordance with ecosystem conditions; Fourth, local potential that has not been based on vertical and horizontal integration; Fifth, the presence of integrators in the integrated farming system has not been paid attention to; The six integrated agricultural systems have not been studied comprehensively and integrally; Seventh, the development of an integrated agricultural system has not been clearly supported by agricultural development policies that have not yet been supported; Eighth, the lack of technology to support an integrated farming system that is understood by farmers, even though in reality it provides more income.

The challenge of implementing IFS is that it relies on resource support, policy support and market conditions. So that the success of implementing IFS varies in each region. As is the case in Zimbabwe and South Africa. Differences in resources, policies, and market conditions have an impact on agricultural productivity [18]. In addition, physical and human capital factors also affect agricultural productivity. Human capital is a challenge for IFS implementation in Indonesia. From BPS data 2018, only $8.54 \%$ of farmers graduated from high school, the majority had not graduated from elementary school, 10,358,754 people or $26.54 \%$. Meanwhile, according to Nurcholis [19] said that the challenge of IFS is that farmers must be able to find a combination of plants, animals and inputs that lead to on high productivity and safe production for consumption. other than that IFS implementation has challenges in the form of high initial costs, good managerial skills, limited access to markets, credit, and information.

Archer et al [2], in facing various challenges of IFS implementation, it is necessary to increase the knowledge and skills of farmers through training and research at the local level. Increased knowledge and skills also need to be supported by the use of technology that can help deal with the complexities of implementing this system. Future developments in technology, regulation, labor availability, and demand for food and ecosystem services will influence the adoption of integrated agricultural systems, which have a key role to play in meeting future food needs.

In carrying out IFS activities, it is also necessary to emphasize sustainable agricultural development in rural areas. This relates to the time it takes to get results, organizational flexibility, labor requirements, IFS implementation costs and Government support. In the initial activities in implementing the IFS program there was a need to develop the capacity of the workforce through training. It is necessary to identify the needs of the agricultural system in order to be right on target. The development of agricultural systems requires supportive supportive policies, institutions, services, and public investment in rural areas [20].

\section{Conclusion}

The implementation of IFS is very important because it has many advantages. However, it can be said that more positive impacts are obtained, namely the optimization of narrow agricultural land and is very suitable to be applied to rural areas because it has a small scale. In general, the challenges of implementing IFS are limited knowledge and skills of farmers, 
limitations in the use of technology, and access to capital. To deal with the above challenges, support from the government is needed in the form of training support and policy assistance, investment and easy access to capital so that IFS can be implemented properly and be able to encourage sustainable agriculture in Indonesia.

\section{References}

1. A. K. Patra, Concept, scope and components of integrated farming system. Training Manual- A Model Training Course on Root and Tuber Crop Based Integrated Farming System: A way forward to Address Climate Change and Livelihood Improvement. 8-13 (2016)

2. D. W. Archer, J. G. Franco, J. J. Halvorson, K. P. Pokharel. Integrated Farming Systems. USDA Agricultural Research Service, Northern Great Plains Research Laboratory, Mandan, ND, Unites States. Encyclopedia of Ecology, 2nd Edition (2018)

3. R. Garrett, O. Cortner, J. D.B. Gil , J. C. d. Reis, J. Ferreira, J. F. Valentim. Challenges and Opportunities for the Adoption of Integrated Farming Systems: Lessons from Brazil and Beyond. International Symposium on Agricultural Technology Adoption: studies, methods and experiences (2020)

4. M. P. Russelle, M. H. Entz, A. J. Franzluebbers. Agronomy Journal 99(2):325-334 (2007)

5. J. D. Hanson, A. J. Franzluebbers, Renewable Agriculture and Food Systems, 23, 263264 (2008)

6. J.R. Hendrickson, G. Sassenrath, D. Archer, J. D. Hanson, J. Halloran, Renewable Agriculture and Food Systems, 23, 314-324. (2008)

7. P. Vereijken. Agricultural Systems 30 (2): 187-197 (1989).

8. S. Radhammani, A. Balasubramanian, K. Ramamoorthy, V. Geethalakshmi. Agricultural Reviews Bangladesh, 24, 204-210 (2003)

9. C. Jayanthi, C. Vennila. Integrated farming systems and sustainability for livelihood security. National Symposium on New Paradigms in Agronomic Research. Pp., 281-284 (2008)

10. B. N. Thorat, B. M. Thombre, A. V. Dadge. International Journal of Tropical Agriculture, Vol. 33, No. 2, pp. 653-657 (2015)

11. J. P. Chavas. Journal of Agricultural and Resource Economics 52(4):365-380 (2008)

12. S. Patra, P. SamalJournal of Pharmacognosy and Phytochemistry 2018; 7(3): 3632-3636 (2018)

13. K. Hilimire. Journal of Sustainable Agriculture, 35:4, 376-393 (2013)

14. A. J. Duncan, S. A. Tarawali, P. J. Thorne, D. Valbuena, K. Descheemaeker, S.H.K Tut, Integrated Crop-Livestock Systems-a Key to Sustainable Intensification in Africa, Zimbabwe, Tropical Grasslands-Forrajes Tropicales Volume 1, pp. 202-206 (2013)

15. I. S. Anugrah, S. Sarwoprasodjo, K. Suradisastra, N. Purnaningsih. Forum Penelitian Agro Ekonomi, Volume 32 No. 2, Desember 2014: 157 - 176 (2014)

16. A. K. Aare, J. Egmose, S. Lund, H. H. Nielsen. Agroecology and Sustainable Food Systems. 45:3, 390-416 (2021)

17. F. Hidayati, Yonariza, Nofialdi, D. Yuzaria. JIA (Jurnal Ilmiah Agribisnis) : Jurnal Agribisnis dan Ilmu Sosial Ekonomi Pertanian: 5(3):74-83 (2020)

18. S. M. Uvaneswaran \& S. Keerthana. Pezzottaite Journals 4, 2 (2015)

19. M. Nurcholis, G. Supangkat, Pengembangan Integrated Farming System Untuk Pengendalian Alih Fungsi Lahan Pertanian. Prosiding Seminar Nasional Budidaya Pertanian, 71-84 (2011) 
20. S. Kumar, A. Dey, U. Kumar, N. Chandra, B. P. Bhatt. Integrated Farming System for Improving Agricultural Productivity. Status of Agricultural Development in Eastern India. Hal: 205-230 (2012)

21. A. S. Chnnabasavanna, D.P. Biradar. Karnataka Journal of Agricultural Sciences, 20(4):706-709 (2007)

22. B. L. Manjunath, C. J. Itnal. Indian Journal of Agronomy. 48(1):4-8. (2003)

23. S. P. Tiwari, R. Ravi, Nandeha KL, Vardia HK, Sharma RB, Rajgopal S. Indian Journal of Animal Science, 69(6):448-52. (1999)

24. V. S. Shanmugasundaram, M. Baluswamy. Farming System. 9:105-107. (1993)

25. V.S Shanmugasundaram, M. Baluswamy, A. Rangaswamy. Journal of Farming Systems Research \& Development. 1(1-2):1-9. (1995)

26. G. Ganesan, K. N. Chinnasamy, A. B. Subramanian, P. Manickasundram. Farming Systems Newsletter. 1(2):14. (1990)

27. C. Jayanthi, A. Rangasamy, S. Mythili, M. Balusamy, C. Chinnusamy, N. Sankaran . Sustainable productivity and profitability to integrated farming systems in low land farms. In: Extended summaries, 79-81. (2001)

28. M. Balusamy, P. M. Shanmugham, R. Baskaran. 41(11-12):20-25 (2003)

29. G. Singh. Farming systems options in sustainable management of national resources. In: Proceedings National Symposium on Alternative Farming Systems held at PDCSR, Modipuram. 16-18:80-94 (2004)

30. V. B. Shelke, S. N. Kulkarni, D. B. Waghmore, A. Chavan. Study on Integrated Farming System in Marathwada. Extended Summaries: 1st National Symposium on Farming System Research in New Millennium held at PDCSR, Modipuram. 15-17:99-100 (2001)

31. D. Bransby, B. E. Gamble, B. Gregory, M. Pegues, R. Rawls. Feedlot gains on forages: Alabama's stocker cattle can make significant gains on ryegrass pastures. Alabama Agriculture Experiment Station, Auburn University, AL (1999)

32. G. M. Hill, R. K. Hubbard, R. C. Lacy, C Blalock. Integration of winter grazing and irrigated cotton production, pp. 40-45 2003 Georgia Cotton Research and Extension Reports. UGA/CPES Res.-Ext. Publ. 6. University of Georgia CAES and USDAARS, Athens, GA (2004)

33. P. Lowy. Integrating poultry and sheep on vegetable cropping land for increased economic return and enhanced fertility. Sustainable Agriculture Research and Education Project Database; Farmer/Rancher Project; Region: Northeast (2009)

34. G. Siri-Prieto, D. W. Reeves, R. L. Raper. Soil Science Society of America Journal 71:197-205 (2007)

35. N. P. Sukanteri. Pemodelan Sistem Pertanian Terintegrasi Pendekatan: Programasi Linier. Tesis. Bidang Ilmu Agribisnis. Program Pascsarjana, Universitas Udayana. Denpasar (2013)

36. E. Pasandaran, I. K. A. Djayanegara, IK. Kariyasa, dan F. Kasryno. Integrasi Tanaman Ternak di Indonesia. Badan Penelitian dan Pengembangan Pertanian. Jakarta (2006)

37. S. Guntoro, N. Badung, A. Gunawan, Sriyanto. Laporan Akhir Prima Tani Lahan Kering Dataran Tinggi Iklim Basah di Kabupaten Buleleng. Balai Pengkajian Teknologi Pertanian Bali. Denpasar (2009)

38. N. Adijaya, W. Trisnawati, K. Mahaputra, K. Agus. Laporan Akhir Prima Tani Lahan Kering Dataran Rendah Iklim Kering di Kabupaten Buleleng. Balai Pengkajian Teknologi Pertanian Bali. Denpasar (2009)

39. IK.T. Wibawa \& IN.M. Yasa.. E-Jurnal EP Unud 2(6): 314-324 (2013) 